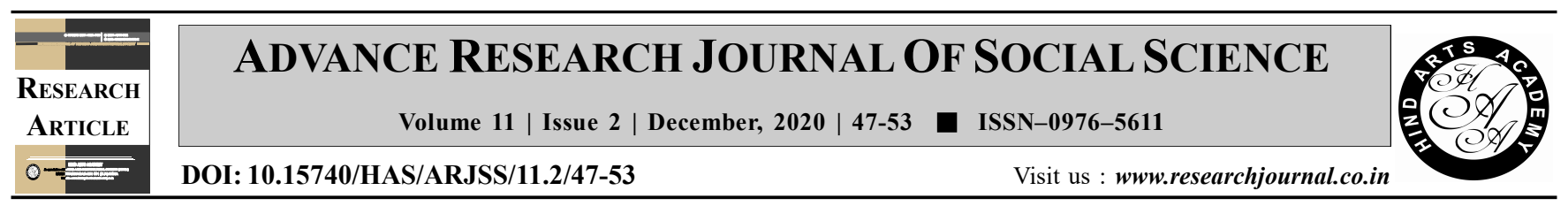

\title{
The status of value orientation among rural and urban adolescents
}

Manpreet Kaur* and Tejpreet Kaur Kang Department of Human Development and Family Studies, Punjab Agricultural University, Ludhiana (Punjab) India (Email : manpreetjkbro@gmail.com)

\section{ARTICLE INFO :}

Received : 08.07 .2020

Revised : 17.08 .2020

Accepted : 11.09 .2020

KEY WORDS :

Values, Value orientation

HOW TO CITE THIS ARTICLE :

Kaur, Manpreet and Kang, Tejpreet Kaur (2020). The status of value orientation among rural and urban adolescents. $A d v$. Res. J. Soc. Sci., 11 (2): 47-53, DOI: 10.15740/HAS/ARJSS/11.2/4753.Copyright@2020:HindAgriHorticultural Society

*Author for correspondence

\begin{abstract}
The present study entitled 'the status of value orientation among rural and urban adolescents' was undertaken in the Ludhiana and Kapurthala districts of Punjab. The study was designed to sassess the status of value orientation among rural and urban adolescents. The sample for the present study comprised of 480 adolescents within the age group of 16-18 years [boys $(\mathrm{n}=120)$ and girls $(\mathrm{n}=120)$ from rural $(\mathrm{n}=120)$ as well as urban area $(n=120)]$. Personal Value Questionnaire by Sherry and Verma was used to assess the value orientation of adolescents. The scale consisted of 40 items representing ten types of values namely Religious Values, Social Values, Democratic Values, Aesthetic Values, Economic Values, Knowledge Values, Hedonistic Values, Power Values, Family Prestige Values and Health Values. Results revealed that more number of urban females were having high level of aesthetic value, knowledge value, power value and health value whereas more number of rural females had high level of social value and total value orientation. More number of rural males were having high level of power value and health value. More number of rural respondents had low level of aesthetic value in value orientation as compared to urban respondents.
\end{abstract}

